\title{
The Ethical Perception of Engineering Students Who Have Never Participated in the Ethics Curriculum
}

\author{
https://doi.org/10.3991/ijep.v12i1.21781 \\ Nguyen Van Hanh, Nguyen Tien Long $\left({ }^{\bowtie}\right)$ \\ Hanoi University of Science and Technology, Hanoi, Vietnam \\ Long.nguyentien@hust.edu.vn
}

\begin{abstract}
Existing studies on the ethical perception of engineering students are based on observations among students who have participated in the ethical courses of engineering schools. Whether the students have never participated in the engineering ethics curriculum, can they perceive the specific ethical codes that apply to engineers? Therefore, the purpose of this study is to examine the ethical perception of students who have never participated in the ethics curriculum. The results of quantitative analysis from survey data with 654 Vietnamese engineering students show that the students have a positive perception of specific ethical codes that apply to engineers. The voluntary blood donation factor is not correlated with the ethical perception of engineering students. Gender, student year, GPA and students' opinion on technology are factors that have different effects on students' perception of different codes of ethics.
\end{abstract}

Keywords—engineering students, ethical perception, ethics courses, engineering ethics, ethics curriculum

\section{$1 \quad$ Introduction}

Ethics is an important aspect in developing the professional identity of engineers $[4,5]$. Several recent studies show a growing interest in engineering universities about improving the ethical knowledge of their students and the training of pre-engineers with ethical responsibility $[3,19,26]$. Ethical decision-making is essential to the engineering profession, and ethical education should be a fundamental task in training engineering students [22]. Engineering ethics education can reinforce the tendency to act ethically and build a solid foundation in ethical decision-making for students [3, 15]. Students taking an ethics-based course or module is more likely to realize the core of an ethics problem in a certain complex situation than students with no previous experience [3]. However, those findings came from observations among students who have participated in the ethics courses in the engineering school. Using the keyword "engineering ethics" and searching the ERIC and Google Scholar databases, the researchers did not find any literature examining the ethical perceptions of engineering students who have never participated in the ethics curriculum. This indicates a knowledge gap in the existing literature to answer the question of whether engineering students are able to recognize the specific ethical codes that apply to engineers. 
Therefore, the purpose of this study is to examine the ethical perception of students who have never participated in the ethics curriculum.

While it is possible that the students have never participated in the ethics curriculum, there is absolutely no ambiguity in the assertion that students may have heard about ethical issues in talks at home, on the TV, on the streets, among friends, or some have personally experienced ethical issues at work, or working on projects [4]. These exposures or experiences can naturally help students attain a certain level of ethical knowledge and reinforce students' inclination to act ethically and build a solid foundation in their ethical decision-making skills. Furthermore, some researchers seem to disagree that students who attend an ethical course or module are more likely to recognize the core of a moral issue than students who have not had any such prior experience [3]. In addition, existing studies indicate that many engineering curriculum provides very little opportunity for students to systematically learn ethical behavior, and the production of ethical behavior is also very complex of individual psychological processes [4]. Some other studies have argued that ethics cannot be taught in the direction of ethical behavior, but they propose that ethical reasoning (or ethical justification) is teachable [28]. So, by examining the ethical perception of engineering students who have never participated in the ethics curriculum, we can better understand the ability of students to recognize the ethical codes. With this understanding, policymakers and instructors can plan engineering ethics courses and teach engineering ethics more effectively to students.

\section{Theoretical framework}

\subsection{Codes of engineering ethics}

Existing studies indicate two perspectives of the approach to teaching engineering ethics in universities [15]. In the first view, philosophers provide the engineering ethics courses that help students to learn the ethical standards that apply to engineers by using rational justification for ethical codes from philosophical origins [15]. In the second view, engineering instructors often provide courses on ethical standards by giving students practice discussion and debate on the ethical cases of the engineering profession [2, 25]. Regardless of the approach taken, the code of ethics is a central theme of the engineering ethics course [28]. In fact, there are many different codes of ethics for different areas of engineering. For example, the code of NSPE, ABET and NIEE apply to all areas of engineering, while the code of ASME, IEEE, AIchE, ASCE apply separately to each area of engineering. Those different codes are enforced by the professional organizations that apply them, for example, an IEEE member licensed as a professional engineer may be subject to IEEE's ethical codes [9]. The researchers found two perspectives on the description of codes of ethics by professional organizations. A set of short codes for generality, such as the IEEE's code, can obscure engineers' disagreement about how they should behave in an ethical situation, while a set of long codes, such as NSPE's code, which provides a lot of specific instructive information for engineers to implement as they spend time reading them [9]. 
Although the codes are described as a statute, in fact, those codes are more like a guide to conscience, professional responsibility, or public judgment. The code is also easy for engineers to read, understand and apply it [9]. This implies that engineering students can also perceive these codes of ethics in their work.

Research question 1: Engineering students who have never participated in the ethics curriculum, how do they perceive the codes of ethics?

\subsection{Factors affecting engineering students' ethical perception}

Engineering ethics often focuses mainly on the ethics of engineers, who act as individuals in the field of engineering [6]. A paradigm of the moral engineer prevails as a "moral hero", it is considered as a contemporary thinking in engineering ethics [1, 6]. A moral hero tends to be both personality and manly to cope with every possible moral challenge [1,6]. Although individual engineers play a central role in ethical situations, they are not the sole actor in the matter. Ethics exists in the field of engineering as a part of the complex relationships between many other people, organizations, and groups [6]. Therefore, in some recent studies, a paradigm of feminist engineering ethics has been approached to comprehensively complement an awareness of gender into engineering ethics [6, 23]. Women seem more sensitive to engineering ethical situations [28]. Bairaktarova et al. imply that many variables such as age and work experience, social activities and cultural background play a role in ethical decisions [4].

In a research report of about 200 college students in the United States, it was revealed that there was no relationship between the grade point average (GPA) and the students' ethical perception [27]. Although this result is somewhat surprising, perhaps it must be further confirmed in the area of engineering ethics.

The final factor of interest in this study, the way students perceive technology, does it affect the students' ethical perception? By creating and using technologies, humans have achieved a high degree of independence from nature [6]. Human lives are increasingly intertwined with complex technological systems that we constantly delegate to them new tasks and powers. However, safety concerns are also growing everywhere as technologies could be misused from the original purpose, such as privacy rights and GPS technology, pregnancy screening technology. A philosophical view is that technology is neutral, neither good nor bad, and what matters is how we use it [16]. While the opposite direction, a philosophical view is that society is at fault in developing and implementing those technologies [13]. That gives us reason to believe that students' opinions on technology affect their ethical perception.

Research question 2: Gender, student year, volunteering activity, GPA, opinions on technology of students, among them, what are the factors that influence the ethical perception of engineering students? 


\section{$3 \quad$ Methodology}

\subsection{Design}

This study was a survey design in which online questionnaires were used to examine the ethical perception of students who have never participated in engineering ethics curriculum. The online survey was conducted in the second half of 2019 to the first half of 2020 to test the ethical awareness of engineering students at Hanoi University of Science and Technology, Vietnam. HUST is the most prestigious engineering university in Vietnam $[17,18]$. However, in HUST's engineering programs, ethics has not yet become an independent course or integrated across the engineering curriculum. That means that HUST's students have never been in ethics courses. All of the students participating in the survey have experience for at least one semester of study in engineering subjects. At HUST, this meant that all responses were from the second-year students and above. The online questionnaires were branched out, and if the participants were not second-year students and above, they would not continue to participate in the questionnaire. The convenience sampling techniques have been used to collect data from all the courses that researchers' colleagues are working on.

\subsection{Instrument}

The measuring instrument is designed with two main groups of questions:

The first group of questions was to collect data on the characteristics of engineering students, including gender, student year, GPA, and voluntary blood donation of students. Question No. 28 designed by Tucker and Ferguson was used to collect students' opinion on technology [29].

The second group of questions was to collect data about the ethical perception of engineering students. Because the ethical codes of engineers differ from country to country as a result of diverse cultural, educational, and professional backgrounds [4]. While the Vietnamese engineering society has not yet developed ethical codes for engineers, this study is based on the NSPE Code of Ethics for Engineers of the National Society of Professional Engineers, USA [20]. The NSPE's Ethical Codes are used by researchers because they are long and detailed, non-abstract, and are applicable to all fields of engineering [9]. A list of ethical behaviors have been carefully developed corresponding to each code in the NSPE Code of Ethics for Engineers. Then, a seminar in our research team was conducted to eliminate ambiguous ethical behaviors in the Vietnamese engineering society, as it could lead to reactions of inconsistent ethical perception among students. A total of 27 ethical behaviors were carefully selected to collect the students' responses. Students were asked to rate these ethical behaviors by five levels, including: $1=$ Not at all unethical, $2=$ Not particularly unethical, $3=$ Somewhat unethical, $4=$ Basically unethical, $5=$ Very unethical.

The measuring instrument of ethical behavior was tested for internal reliability. According to Cortina, a "Cronbach's alpha" value higher than ' 0.70 ' actually reflects 
internal consistency, regardless of the number of responses [8]. If the 'Corrected Item - Total Correlation' value is less than '0.3' and 'Cronbach's Alpha if Item Deleted' value is greater than a 'Cronbach's Alpha' value, they are used to remove items that don't fit in the scale.

The results of the internal reliability analysis of the measuring instrument were shown in Table 1.

In Table 1, the internal reliability analysis for the original variables obtained a Cronbach alpha value of 0.932 , which was greater than the standard value of 0.7 . However, the variable 'I1' was removed because its "Corrected Item - Total Correlation" value of 0.275 was less than 0.3 . Result of the second internal reliability analysis obtained a Cronbach alpha value of 0.932 greater than the standard value 0.7 . In all item cases, the "Corrected Item - Total Correlation" values were greater than 0.3, and "Cronbach's Alpha if Item Deleted" values were no greater than a overall Cronbach alpha value of 0.932 . Therefore, the internal reliability of the measuring instrument was acceptable. 
Table 1. Internal reliability analysis

\begin{tabular}{|c|c|c|c|}
\hline Code & Items & $\begin{array}{c}\text { Corrected } \\
\text { Item-Total } \\
\text { Correlation } \\
\text { (Initial / } \\
\text { Revised) } \\
\end{array}$ & $\begin{array}{c}\text { Cronbach's } \\
\text { Alpha if Item } \\
\text { Deleted } \\
\text { (Initial / } \\
\text { Revised) } \\
\end{array}$ \\
\hline I1. & $\begin{array}{l}\text { Not report to the responsible parties in the circumstances that could endanger life } \\
\text { and property of the public. }\end{array}$ & .275 / Delete & $\begin{array}{c}.932 / \\
\text { Unavailable }\end{array}$ \\
\hline $\mathrm{I} 2$. & $\begin{array}{l}\text { Approval of engineering documents that are not in conformity with applicable } \\
\text { standards. }\end{array}$ & $.447 / .441$ & $.931 / .932$ \\
\hline $\mathrm{I} 3$. & $\begin{array}{l}\text { Reveal facts, data, or information without the prior consent of the client or } \\
\text { employer. }\end{array}$ & $.525 / .522$ & $.930 / .931$ \\
\hline I4. & $\begin{array}{l}\text { Permit the use of their name or associate in business ventures with any person or } \\
\text { firm that they believe is engaged in fraudulent or dishonest enterprise. }\end{array}$ & $.504 / .501$ & $.930 / .931$ \\
\hline I5. & Aid or abet the unlawful practice of engineering. & $.408 / .405$ & $.931 / .932$ \\
\hline I6. & Undertake assignments beyond education and experience in the technical field. & $.433 / .433$ & $.932 / .932$ \\
\hline I7. & $\begin{array}{l}\text { Sign engineering plans or documents that are not controlled by the engineer } \\
\text { himself or lack competence. }\end{array}$ & $.585 / .584$ & $.929 / .930$ \\
\hline I8. & $\begin{array}{l}\text { Accept coordination, signing the engineering documents of an entire project when } \\
\text { each technical segment has not been signed by the qualified engineers. }\end{array}$ & $.554 / .554$ & $.929 / .930$ \\
\hline I9. & Lack of objectivity and honesty in professional reports, statements, or testimony. & $.678 / .678$ & $.928 / .928$ \\
\hline I10. & $\begin{array}{l}\text { Accept compensation, financial considerations or otherwise, from more than one } \\
\text { party for services on the same project, when the circumstances are fully disclosed } \\
\text { and agreed to by all interested parties. }\end{array}$ & $.592 / .595$ & $.929 / .930$ \\
\hline I11. & $\begin{array}{l}\text { Falsifying the qualifications of engineer himself and their associates; advertise } \\
\text { false information about competences and past accomplishments. }\end{array}$ & $.650 / .652$ & $.928 / .929$ \\
\hline I12. & Pay a commission, percentage, or illegal brokerage fee in order to secure work. & 621 & .929 \\
\hline I13. & Not acknowledge errors and distort or alter the facts. & $.600 / .600$ & $.929 / .930$ \\
\hline I14. & $\begin{array}{l}\text { Not advise their clients or employers when believing a project will not be } \\
\text { successful. }\end{array}$ & $.649 / .650$ & $.928 / .929$ \\
\hline I15. & Accept outside employment to the detriment of their regular work. & $.652 / .654$ & $.928 / .929$ \\
\hline I16. & $\begin{array}{l}\text { Attempt to attract an engineer from another employer by false or misleading } \\
\text { pretenses. }\end{array}$ & $.695 / .698$ & $.927 / .928$ \\
\hline I17. & Trade the dignity and integrity of the profession for promoting their own interests. & $.599 / .600$ & $.929 / .929$ \\
\hline I18. & $\begin{array}{l}\text { Complete and sign plans and/or specifications that are not in conformity with } \\
\text { applicable engineering standards. }\end{array}$ & $.650 / .649$ & $.928 / .929$ \\
\hline I19. & Not keep up to date with the latest developments in area of the engineer himself. & $.529 / .531$ & $.930 / .931$ \\
\hline $\mathrm{I} 20$. & $\begin{array}{l}\text { Engage in conduct or practice that deceives the public, meaning that the use of } \\
\text { statements containing a material misrepresentation of fact, or omitting a material } \\
\text { fact. }\end{array}$ & $.555 / .553$ & $.929 / .930$ \\
\hline $\mathrm{I} 21$. & $\begin{array}{l}\text { Disclose, without consent, confidential information concerning the business affairs } \\
\text { or technical processes of any present or former client or employer on which they } \\
\text { serve. }\end{array}$ & $.596 / .595$ & $.929 / .930$ \\
\hline $\mathrm{I} 22$. & $\begin{array}{l}\text { Accept commissions, financial or other considerations from any party related to } \\
\text { the work for which the engineer is responsible. }\end{array}$ & $.555 / .558$ & $.930 / .930$ \\
\hline $\mathrm{I} 23$. & $\begin{array}{l}\text { Attempt to obtain employment or advancement or professional engagements by } \\
\text { untruthfully criticizing other engineers, or by other improper methods. }\end{array}$ & $.600 / .600$ & $.929 / .930$ \\
\hline $\mathrm{I} 24$. & $\begin{array}{l}\text { Without consent, use equipment, supplies, laboratory, or office facilities of an } \\
\text { employer to carry on outside private practice. }\end{array}$ & $.674 / .675$ & $.928 / .928$ \\
\hline $\mathrm{I} 25$. & Pass blame for errors to an innocent co-worker. & $.558 / .557$ & $.929 / .930$ \\
\hline I26. & $\begin{array}{l}\text { Using designs supplied by a client without recognize that the designs remain the } \\
\text { property of the client and duplicated it for others without express permission. }\end{array}$ & $.575 / .572$ & $.929 / .930$ \\
\hline I27. & $\begin{array}{l}\text { All matters related to copyrights of other engineers are ignored, when undertaking } \\
\text { work for others in connection with which the engineer may make improvements, } \\
\text { plans, designs or other records. }\end{array}$ & $.509 / .509$ & $.930 / .931$ \\
\hline
\end{tabular}




\subsection{Data analysis}

Quantitative analyzes in SPSS were conducted for all the data collected. In the initial analysis, the descriptive statistics were conducted for data on student characteristics including gender, student year, GPA, voluntary blood donation of students, and students' opinion on technology. Then, a Exploratory Factor Analysis (EFA) was used to examine the scale's dimensionality. Finally, there were linear regression analyzes.

EFA was conducted for the scale to examine its dimensionality. A cut-off point of 0.45 of the KMO (Kaiser-Meyer-Olkin) value was used to examine the relevance of factor analysis [7]. Principal components analysis was used to find patterns in the large datasets [10]. The eigenvalue value was not less than 1.00 and the total variance of the measuring factors is not less than $50 \%$, which will be explained by the alternative common factor [11]. Rotated Component Matrix analysis was conducted to examine the convergent and discriminant validity of the independent variables loading an alternative common factor. The values of factor loading of the variable must not be less than ' 0.5 ' to ensure convergent validity [14]. In the same row, the values of the factor loading of each variable must be separated by at least ' 0.3 ' to ensure discriminative validity.

Linear regression analysis was used to examine the effect of students 'characteristics (such as gender, student year, GPA, voluntary blood donation of students, students' opinion on technology) on the ethical perception of engineering students. Determining whether a regression structure was statistically significant based on the amount of "change in $\mathrm{R}^{2 \text { " }}$ and its associated p-value [12].

The ethical perception of students was represented by means and standard deviations. We used the following scoring system designed by [24], including: 1.00 $1.44=$ Not at all unethical; $1.45-2.44=$ Not particularly unethical; $2.45-3.44=$ Somewhat unethical; $3.45-4.44=$ Basically unethical; $4.45-5=$ Very unethical. The mean value of 3.45 was fixed as the cut-off point [21], meaning that a variable was perceived as 'unethical' if the mean score of 3.45 or higher [24]. The variable received a mean value of 4.45 , which was determined to be 'very unethical' by the students [ 21 , 24].

\section{$4 \quad$ Results}

\subsection{Sample characteristics}

In the two weeks since the online survey was conducted, we have received 969 respondents. The average time to complete a questionnaire about 13 minutes. There were 654 responses that were considered valid when no items were left blank.

The results of the sample characteristic analysis are shown in Table 2. 
Table 2. Sample characteristics

\begin{tabular}{|c|c|c|}
\hline Category & Frequency & Percentage \\
\hline \multicolumn{3}{|l|}{ Gender } \\
\hline Male & 461 & 70.5 \\
\hline Female & 193 & 29.5 \\
\hline Total & 654 & 100 \\
\hline \multicolumn{3}{|l|}{ Student year } \\
\hline Second year & 137 & 20.9 \\
\hline Third year & 446 & 68.2 \\
\hline Fourth year and higher & 71 & 10.9 \\
\hline Total & 654 & 100 \\
\hline \multicolumn{3}{|l|}{$G P A$} \\
\hline$<1.99$ & 77 & 11.8 \\
\hline$\geq 2.0$ to $<2.49$ & 282 & 43.1 \\
\hline$\geq 2.5$ to $<3.19$ & 241 & 36.9 \\
\hline$\geq 3.2$ to $\leq 4.0$ & 54 & 8.3 \\
\hline Total & 654 & 100 \\
\hline \multicolumn{3}{|l|}{ Voluntary blood donation } \\
\hline Yes & 339 & 51.8 \\
\hline No & 315 & 48.2 \\
\hline Total & 654 & 100 \\
\hline \multicolumn{3}{|l|}{ Students' opinions on technology } \\
\hline $\begin{array}{l}\text { Engineers must first create new technologies and then find ways they } \\
\text { can be used in society. }\end{array}$ & 83 & 12.7 \\
\hline $\begin{array}{l}\text { Engineers must first identify social needs and then create new tech- } \\
\text { nologies to address them. }\end{array}$ & 571 & 87.3 \\
\hline Total & 654 & 100 \\
\hline
\end{tabular}

\subsection{Exploratory factor analysis}

The EFA was conducted in two tests to examine the data's dimensionality on the ethical perception of engineering students. In the first test, a KMO value of 0.949 was greater than 0.45 , and a p-value of 0.00 was less than 0.05 , but the items I9, I11, I12 and 122 were deleted because these items are load factor in itself (please see Appendix 1). In the second test (Table 3 ), a KMO value of 0.939 was greater than 0.45 , and a p-value of 0.00 was less than 0.05 indicating that the rotated factor loading matrix was statistically significant. The results of Total Variance Explained result an Eigenvalues value of 1.034 (greater than 1) and a Cumulative value of $56.45 \%$ (greater than $50 \%$ ). In other words, the original items explained to $56.45 \%$ of the total variance of the alternative common factors. In all cases, the factor loading values were greater than 0.5 and no items loaded more than two new factors indicating that convergent validity and discriminative validity were accepted. 
Table 3. Factor analysis for the ethical perception of engineering students

\begin{tabular}{|c|c|c|c|c|c|c|}
\hline \multirow{2}{*}{ Code / Item } & \multirow{2}{*}{$\mathbf{M}$} & \multirow{2}{*}{ SD } & \multicolumn{4}{|c|}{ Rotated varimax } \\
\hline & & & Factor 1 & Factor 2 & Factor 3 & Factor 4 \\
\hline $\begin{array}{l}\text { Factor 1: Students' perception for engineers' honesty } \\
\text { and acting as truthful trustees. }\end{array}$ & 4.33 & .586 & & & & \\
\hline 126 & 4.43 & .742 & .740 & & & \\
\hline 125 & 4.37 & .808 & .706 & & & \\
\hline 123 & 4.33 & .797 & .681 & & & \\
\hline I27 & 4.21 & .906 & .631 & & & \\
\hline I21 & 4.50 & .732 & .613 & & & \\
\hline I24 & 4.03 & .884 & .607 & & & \\
\hline $\mathrm{I} 20$ & 4.45 & .755 & .545 & & & \\
\hline $\begin{array}{l}\text { Factor 2: Students' perception for performing ser- } \\
\text { vices only in areas of engineer's competence. }\end{array}$ & 3.63 & .798 & & & & \\
\hline I6 & 2.94 & 1.19 & & .758 & & \\
\hline I19 & 3.34 & 1.24 & & .709 & & \\
\hline I7 & 3.92 & .965 & & .698 & & \\
\hline I8 & 4.04 & .955 & & .659 & & \\
\hline $\mathrm{I} 10$ & 3.90 & 1.02 & & .579 & & \\
\hline $\begin{array}{l}\text { Factor 3: Students' perception for the highest integri- } \\
\text { ty in engineer's relationships. }\end{array}$ & 4.16 & .674 & & & & \\
\hline I15 & 3.97 & .980 & & & .693 & \\
\hline I17 & 4.33 & .856 & & & .666 & \\
\hline I14 & 3.86 & 1.00 & & & .637 & \\
\hline $\mathrm{I} 13$ & 4.45 & .779 & & & .559 & \\
\hline I16 & 4.09 & .872 & & & .553 & \\
\hline $\mathrm{I} 18$ & 4.25 & .808 & & & .536 & \\
\hline $\begin{array}{l}\text { Factor 4: Students' perception for holding para- } \\
\text { mount the safety, health, and welfare of the public } \\
\text { by engineers. }\end{array}$ & 4.46 & .513 & & & & \\
\hline I3 & 4.50 & .712 & & & & .626 \\
\hline I4 & 4.58 & .681 & & & & .526 \\
\hline I2 & 4.35 & .773 & & & & .549 \\
\hline I5 & 4.43 & .804 & & & & .530 \\
\hline Eigenvalues & & $\begin{array}{c}1.03 \\
4\end{array}$ & & & & \\
\hline Cumulative \% & & $\begin{array}{c}56.4 \\
5\end{array}$ & & & & \\
\hline Cronbach's alpha & & & 0.852 & 0.792 & 0.853 & 0.732 \\
\hline
\end{tabular}

$\mathrm{KMO}=0.939, \mathrm{p}=0.000$

In the Table 3 , the rotated factor loading matrix indicates that the 22 original items loaded for the four alternative factors. Based on the general nature of the independent variables loading each alternative common factor, they can be named as follows: 
- Factor 1 (abbreviation: F1) was an alternative variable of a group of independent variables, including I20, I21, I23, I24, I25, I26 and I27, which can be called "Students' perception for engineers' honesty and acting as truthful trustees".

- Factor 2 (abbreviation: F2) was an alternative variable of a group of independent variables, including I6, I7, I8, I10 and I19, which can be called "Students' perception for performing services only in areas of engineer's competence".

- Factor 3 (abbreviation: F3) was an alternative variable of a group of independent variables, including I13, I14, I15, I16, I17 and I18, which can be called "Students' perception for the highest integrity in engineer's relationships".

- Factor 4 (abbreviation: F4) was an alternative variable of a group of independent variables, including I2, I3, I4 and I5, which can be called "Students' perception for holding paramount the safety, health, and welfare of the public by engineers".

Internal reliability analysis for each group of independent variables loading the alternative variable indicating that Cronbach alpha values were greater than ' 0.7 '. This means that the internal reliability of the scales for F1, F2, F3 and F4 is acceptable.

\subsection{Correlation analysis}

A Pearson correlation analysis was conducted to detect the correlation (positive / negative) between pairs of independent and dependent variables, which should be done before regression analysis (Table 4). The problem of multicollinearity can be detected when the independent variables are strongly correlated.

Table 4. Matrix of correlation analysis

\begin{tabular}{|c|c|c|c|c|c|c|c|c|c|c|}
\hline & & Gender & $\begin{array}{c}\text { Student } \\
\text { year }\end{array}$ & GPA & VBD & SOT & F1 & F2 & F3 & F4 \\
\hline \multirow{2}{*}{ Gender } & $\mathrm{R}$ & 1 & .021 & $.128^{* *}$ & .074 & $.096^{*}$ & $.114^{* *}$ & .008 & $.087^{*}$ & .073 \\
\hline & $\mathrm{P}$ & & .592 & .001 & .058 & .014 & .003 & .833 & .026 & .063 \\
\hline \multirow{2}{*}{ Student year } & $\mathrm{R}$ & & 1 & .032 & -.040 & -.003 & -.056 & $-.086^{*}$ & -.054 & -.058 \\
\hline & $\mathrm{p}$ & & & .407 & .310 & .937 & .153 & .028 & .197 & .136 \\
\hline \multirow{2}{*}{ GPA } & $\mathrm{R}$ & & & 1 & .011 & .003 & -.022 & -.003 & -.017 & $.094^{*}$ \\
\hline & $\mathrm{p}$ & & & & .771 & .939 & .582 & .939 & .664 & .017 \\
\hline \multirow{2}{*}{$\begin{array}{l}\text { Voluntary blood } \\
\text { donation (VBD) }\end{array}$} & $\mathrm{R}$ & & & & 1 & $.101^{* * *}$ & .015 & -.048 & .006 & .001 \\
\hline & $\mathrm{p}$ & & & & & .010 & .697 & .222 & .878 & .976 \\
\hline \multirow{2}{*}{$\begin{array}{l}\text { Students' opinions } \\
\text { on technology } \\
\text { (SOT) }\end{array}$} & $\mathrm{R}$ & & & & & 1 & $.080^{*}$ & $-.132^{* * *}$ & -.009 & $.110^{* *}$ \\
\hline & $\mathrm{p}$ & & & & & & .041 & .001 & .818 & .005 \\
\hline \multirow{2}{*}{$\mathrm{F} 1$} & $\mathrm{R}$ & & & & & & 1 & $.486^{* *}$ & $.699^{* *}$ & $.589^{* *}$ \\
\hline & $\mathrm{p}$ & & & & & & & .000 & .000 & .000 \\
\hline \multirow{2}{*}{$\mathrm{F} 2$} & $\mathrm{R}$ & & & & & & & 1 & $.613^{* * *}$ & $.470^{* *}$ \\
\hline & $\mathrm{p}$ & & & & & & & & .000 & .000 \\
\hline \multirow{2}{*}{ F3 } & $\mathrm{R}$ & & & & & & & & 1 & $.596^{* *}$ \\
\hline & $\mathrm{p}$ & & & & & & & & & .000 \\
\hline
\end{tabular}




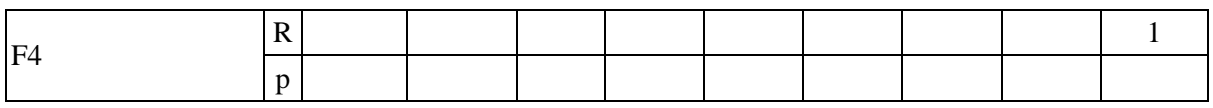

${ }^{* *} \mathrm{p}$-value at the 0.01 level (2-tailed); ${ }^{*} \mathrm{p}$-value at the 0.05 level (2-tailed).

In Table 4, a case where the p-value was greater than 0.05 indicating that the voluntary blood donation factor was not correlated with the ethical perception of engineering students. In other cases, p-values were less than 0.05 indicating that: gender factor was positively correlated with F1 $(\mathrm{R}=0.114)$ and F3 $(\mathrm{R}=0.087)$; student year was negatively correlated with F2 $(\mathrm{R}=-0.086)$; GPA factor positively correlated with F4 $(\mathrm{R}=0.094)$; students' opinions on technology was positively correlated with F1 $(\mathrm{R}=0.080)$ and F4 $(\mathrm{R}=0.110)$, and negatively correlated with $\mathrm{F} 2$ $(\mathrm{R}=-0.132)$. Finally, the low correlation between the independent variables indicates that the problem of multicollinearity was rejected in the following regression analysis.

\subsection{Regression analysis}

The linear regression analyses were conducted to examine the effects of students' characteristics on the ethical perception of engineering students. The results of regression analyses were shown in Table 5.

Table 5. Linear regression results

\begin{tabular}{|l|c|c|c|c|c|}
\hline $\begin{array}{c}\text { Dependent } \\
\text { Variable }\end{array}$ & $\begin{array}{c}\text { Independent } \\
\text { Variable }\end{array}$ & $\mathbf{R}^{2}$ & Adjusted $\mathbf{R}^{2}$ & $\mathbf{p}$ & $\begin{array}{c}\text { Beta (95\% } \\
\text { Confidence Interval) }\end{array}$ \\
\hline F1 & Gender & .013 & .012 & .003 & $.114(.048$ to .245$)$ \\
\hline F1 & $\begin{array}{c}\text { Students' opinions on } \\
\text { technology }\end{array}$ & .006 & .005 & .041 & $.080(.006$ to .275$)$ \\
\hline F2 & Student year & .007 & .006 & .028 & $-.086(-.234$ to -.014$)$ \\
\hline F3 & $\begin{array}{c}\text { Students' opinions on } \\
\text { technology }\end{array}$ & .017 & .016 & .001 & $-.132(-.498$ to -.133$)$ \\
\hline F4 & Gender & .008 & .006 & .026 & $.087(.016$ to .242$)$ \\
\hline F4 & GPA & .009 & .007 & .017 & $.094(.011$ to .109$)$ \\
\hline
\end{tabular}

In all cases, the p-values were less than 0.5 and the adjusted $\mathrm{R} 2$ values were positive indicating the significant relationships between pairs of the independent and dependent variables. Based on the value of Beta, key findings are drawn, including:

- The gender factor has a positive impact on the students' perception for honesty and the truthful trustee of engineers $(\mathrm{B}=0.114,95 \% \mathrm{CI}=0.048$ to 0.245$)$. In other words, the female students were significantly associated with the high scores of students' perception for the engineers' honesty. Similarly, students who argue that engineers must first identify social needs and then create new technologies to address them, they have a positive perception on the honesty and truthful trustee of engineers ( $\mathrm{B}=0.08,95 \% \mathrm{CI}=0.006$ to 0.275 ). In other words, the students' attitude 
towards social responsibility of engineers were significantly associated with the high scores of students' perception for engineers' honesty.

- The factor of student year has a negative impact on the students' perception (at least true for Vietnamese students) for performing services only in the areas of engineer's competence $(\mathrm{B}=-0.086,95 \% \mathrm{CI}=-0.234$ to -0.014$)$. In other words, the senior students were significantly associated with low scores of students' perception for performing services only in the areas of engineer's competence. Similarly, students who argue that engineers must first identify social needs and then create new technologies to address them, they have a negative perception on performing services only in the areas of engineer's competence $(B=-0.132,95 \% \mathrm{CI}$ $=-0.498$ to -0.133$)$.

- The gender factor has a positive impact on the students' perception for the highest integrity in engineer's relationships ( $\mathrm{B}=0.087,95 \% \mathrm{CI}=0.016$ to 0.242 ). In other words, the female students were significantly associated with the high scores of students' perception for the engineers' integrity.

- The GPA factor has a positive impact on the students' perception for holding paramount the safety, health, and welfare of the public by engineers $(B=0.094$, $95 \% \mathrm{CI}=0.011$ to 0.109$)$. In other words, high GPA scores were significantly associated with the high scores of students' perception for holding paramount the public safety by engineers. Similarly, students who argue that engineers must first identify social needs and then create new technologies to address them, they have a positive perception on holding paramount the public safety by engineers $(\mathrm{B}=$ $0.110,95 \% \mathrm{CI}=0.052$ to 0.287 ). In other words, the students' attitude towards social responsibility of engineers were significantly associated with the high scores of students' perception for holding paramount the public safety by engineers.

\section{$5 \quad$ Discussion and conclusion}

\subsection{Research question 1: Engineering students who have never participated in the ethics curriculum, how do they perceive the codes of ethics?}

From the 27 original ethical behaviors designed by researchers based on the 'NSPE Code of Ethics for Engineers', when analyzing internal reliability and EFA, 22 factors are retained. All 22 variables loading four alternative common factors and those alternative variables reflect the common characteristics of each group of independent variables. Four alternative factors were named, and their mean score was calculated by the average of the independent variables in each group, namely: "engineers' honesty and acting as truthful trustees" (mean $=4.33, \mathrm{SD}=0.586$ ), "performing services only in areas of engineer's competence" (mean $=3.63, \mathrm{SD}=0.798$ ), "the highest integrity in engineer's relationships" (mean $=4.16, \mathrm{SD}=0.674)$, and "holding paramount the safety, health, and welfare of the public by engineers" (mean $=4.46$, $\mathrm{SD}=0.513$ ). It can be seen that these new alternative factors show a high consensus with the six fundamental canons of engineering ethics by NSPE 2019 [20]. The mean values of new alternative factors were greater than 3.45 in all cases indicating that 
students who have never been in the ethics courses, they have a positive perception of engineering ethics. In other words, the students who have never participated in the engineering ethical curriculum, have a positive perception of specific ethical codes that apply to engineers. But two independent variables, namely "I6. Undertake assignments beyond education and experience in the technical field" (mean = 2.94), and "I19. Not keep up to date with the latest developments in area of the engineer himself" (mean = 3.34), which were assigned to "Somewhat unethical" by the students (mean <3.45). This was in contrast to the results of Stappenbelt when they said that these are the most unethical behaviors among Australian students [28]. A question for further research may be ask why there is a difference in ethical perception between Australian and Vietnamese students for those ethical behaviors?

5.2 Research question 2: Gender, student year, volunteering activity, GPA, opinions on technology of students, among them, what are the factors that influence the ethical perception of engineering students?

The results of correlation analysis between pairs of the independent and dependent variables have provided some interesting findings. The high GPA scores were significantly associated with the students' perception for holding paramount the public safety by engineers. This was in contrast to the results of Sikula et al. when they said that there are no significant relationships between high or low GPA and scores on ethical value rankings [27]. Voluntary student activities (typically in Vietnam such as voluntary blood donation) were not correlated with the ethical perception of the engineering students, which has not been explained in previous studies.

In the results of linear regression analysis, gender was a factor affecting the students' perception for the engineers' honesty, and the engineers' integrity. This consensus and explains more clearly the qualitative results of Stappenbelt, who said that the female engineering students responded more strongly to ethical perception than male students [28]. The students' attitude towards social responsibility of engineers are significantly associated with students' perception for engineers' honesty, and holding paramount the public safety by engineers. In the Table 2, 87.3\% of the Vietnamese students said that engineers must first identify social needs and then create new technologies to address them. The senior students and students with an attitude towards social responsibility of engineers are significantly associated with low scores of students' perception for performing services only in the areas of engineer's competence. This partly implies that the Vietnamese students have not really viewed performing services only in the area of the engineers' competence as a code of ethics for engineers (mean $=3.63$ ). More studies are needed to answer the why? And if engineering ethics courses are taken, how will it affect the ethical perception of Vietnamese students? 


\section{Implications for education}

The results in Table 3 show that students who have never participated in the ethics curriculum, have a positive perception for the codes of engineering ethics. This suggests the first implication for education, while the code of ethics is a necessary topic in the ethics curriculum, instructors may not need to teach by explaining the codes in detail to their students. Instead, students should be given the opportunity to demonstrate their understanding of the ethical code and spend time applying it to complex ethical situations. The results in Table 5 show that student year and students' attitude towards social responsibility of engineers are factors that have a negative influence on students' perception for performing services only in the areas of engineer's competence. This suggests the second implication for education that Vietnamese students should be more educated to understand the importance of performing services only in the areas of engineer's competence, and this work should be done more for senior students.

\section{$7 \quad$ Limitations}

The data of this study only reflect the views of Vietnamese students who have never participated in the ethics curriculum. Therefore, the topic of this paper should be further explained in more countries in a future study. In addition, a convenience sampling technique was used which is also a limitation of the data. It should be further tested by a method of probability sampling.

\section{Acknowledgment}

This research is funded by Vietnam National Foundation for Science and Technology Development (NAFOSTED) under grant number 503.01-2019.01.

\section{$9 \quad$ References}

[1] Adam, A. (2001). Heroes or sibyls? Gender and engineering ethics. IEEE technology and society magazine, 20(3), 39-46. https://doi.org/10.1109/44.952764

[2] Alpay, E. (2013). Student-inspired activities for the teaching and learning of engineering ethics. Science and engineering ethics, 19(4), 1455-1468. https://doi.org/10.1007/s11948$\underline{011-9297-8}$

[3] Atesh, M., Ward, T., \& Baruah, B. (2016, September). Analyzing the perception, judgment and understanding of Ethics among Engineering students in Higher Education. In 2016 15th International Conference on Information Technology Based Higher Education and Training (ITHET) (pp. 1-7). IEEE. https://doi.org/10.1109/ITHET.2016.7760702

[4] Bairaktarova, D., \& Woodcock, A. (2014, May). The role of motivation in engineering students': Ethical Decisions. In 2014 IEEE International Symposium on Ethics in Science, Technology and Engineering (pp. 1-4). IEEE. https://doi.org/10.1109/ETHICS.2014. $\underline{6893411}$ 
Paper - The Ethical Perception of Engineering Students Who Have Never Participated in the Ethics...

[5] Barakat, N. (2011). Engineering ethics: A critical dimension of the profession. International Journal of Engineering Pedagogy, 1(2), 24-28. http://dx.doi.org/10.3991/ijep.v1i2. $\underline{1639}$

[6] Basart, J. M., \& Serra, M. (2013). Engineering ethics beyond engineers' ethics. Science and engineering ethics, 19(1), 179-187. https://doi.org/10.1007/s11948-011-9293-z

[7] Cohen, J. (2013). Statistical power analysis for the behavioral sciences. Routledge.

[8] Cortina, J. M. (1993). What is coefficient alpha? An examination of theory and applications. Journal of Applied Psychology, 78(1), 98-104. https://doi.org/10.1037/00219010.78.1.98

[9] Davis, M. (1998). Thinking like an engineer. Studies in the Ethics of a Profession (book). Oxford University Press.

[10] Dunteman, G. H. (1989). Principal components analysis (No. 69). Sage.

[11] Field, A. (2013). Discovering statistics using IBM SPSS statistics. sage.

[12] Gallivan, M. J. (2004). Examining IT professionals' adaptation to technological change: The influence of gender and personal attributes. ACM SIGMIS Database: the DATABASE for Advances in Information Systems, 35(3), 28-49. https://doi.org/10.1145/1017114. $\underline{1017119}$

[13] Green, L. R. (2002). Technoculture: from alphabet to cybersex. Crows Nest, Australia: Allen \& Unwin.

[14] Hair, J.F.; Anderson, R.E.; Tatham, R. L.; Black, W.C. (1998). Multivariate Data Analysis, Fifth Edition, Prentice-Hall: Upper Saddle River.

[15] Hanh, N.V.; Long, N.T.; Duyen, N.T.; Canh, P.T.T.; Long, N.T.; Thang, M.D. (2021). Teaching Engineering Ethics Through a Psychology Course. International Journal of Engineering Pedagogy (iJEP), 11(1), 16-34. https://doi.org/10.3991/ijep.v11i1.14999

[16] Huesemann, M., \& Huesemann, J. (2011). Techno-fix: why technology won't save us or the environment. New Society Publishers.

[17] Hung, T.T., Tuyet, N.T., Long, N.T., \& Hanh, N.V. (2020). The Effect of Positive Learning Culture in Students' Blended Learning Process. Journal of e-Learning and Knowledge Society, 16(3), 68-75. https://doi.org/10.20368/1971-8829/1135218

[18] Lan, H. T. Q., Long, N. T., \& Van Hanh, N. (2020). Validation of depression, anxiety and stress scales (DASS-21): Immediate psychological responses of students in the e-learning environment. International Journal of Higher Education, 9(5), 125-133. https://doi.org/ 10.5430/ijhe.v9n5p125

[19] Monteiro, F. (2017). The Students' Perspective Contribution: Rethink the Ethical Education of Engineering Students. International Journal of Engineering Pedagogy, 7(2), 22-35. https://doi.org/10.3991/ijep.v7i2.6819

[20] National Society of Professional Engineers - NSPE (2019). NSPE Code of Ethics. Available at: https://www.nspe.org/sites/default/files/resources/pdfs/Ethics/CodeofEthics/NSPE CodeofEthicsforEngineers.pdf

[21] Nazim, M., \& Mukherjee, B. (2016). Factors Critical to the Success of Knowledge Management (Chapter 11). Knowledge management in libraries: concepts, tools and approaches (Editor(s): Mohammad Nazim, Bhaskar Mukherjee). Chandos Publishing, 263-286. https://doi.org/10.1016/B978-0-08-100564-4.00011-9

[22] Fleischmann, S. T. (2004). Essential ethics-embedding ethics into an engineering curriculum. Science and Engineering Ethics, 10(2), 369-381. https://doi.org/10.1007/s11948$\underline{004-0033-5}$

[23] Riley, D. (2013). Hidden in plain view: Feminists doing engineering ethics, engineers doing feminist ethics. Science and engineering ethics, 19(1), 189-206. https://doi.org/10. $\underline{1007 / \mathrm{s} 11948-011-9320-0}$ 
[24] Sarrafzadeh, M., Martin, B., \& Hazeri, A. (2010). Knowledge management and its potential applicability for libraries. Library Management, 31 (3), 198-212. https://doi.org/ $\underline{10.1108 / 01435121011027363}$

[25] Sethy, S. S. (2017). Undergraduate engineering students' attitudes and perceptions towards 'professional ethics' course: a case study of India. European Journal of Engineering Education, 42(6), 987-999. https://doi.org/10.1080/03043797.2016.1243656

[26] Stelios, S., \& Christodoulou, A. (2020). Teaching Professional Integrity: An Empirical Study on Engineering Students. International Journal of Engineering Pedagogy (iJEP), 10(3), 98-105. https://doi.org/10.3991/ijep.v10i3.12013

[27] Sikula, A., \& Costa, A. D. (1995). Are gpa and ethics related?. International Journal of Value-Based Management, 8(3), 237-253.

[28] Stappenbelt, B. (2013). Ethics in engineering: student perceptions and their professional identity. JOTSE: Journal of technology and science education, 3(1), 3-10. http://dx.doi. org/10.3926/jotse. 51

[29] Tucker, J., \& Ferguson, D. (2007). Incorporating ethics and social responsibility in undergraduate engineering education. In International Conference on Engineering EducationICEE (pp. 3-7).

\section{Authors}

Nguyen Van Hanh is a Doctor of Philosophy in Education at School of Engineering Pedagogy, Hanoi University of Science and Technology, Vietnam. He graduated with a PhD in 2017 at the Hanoi National University of Education, Vietnam. His main research directions lie in the fields, including: theory and practice in engineering education, theory of educational technology, STEM education, engineering ethics education, experiential education.

Nguyen Tien Long is a Doctor of Mechanical Engineering Education. He is currently the deputy principal (vice-principal) of School of Engineering Pedagogy, Hanoi University of Science and Technology, Vietnam. His main research directions lie in the fields, including: theory and practice in engineering education, practice of educational technology, adult education.

Article submitted 2021-02-05. Resubmitted 2021-09-12. Final acceptance 2021-09-12. Final version published as submitted by the authors.

\section{Appendix 1 - EFA of the original 26 items}

Table 6. KMO and Bartlett's Test

\begin{tabular}{|l|c|c|}
\hline Kaiser-Meyer-Olkin Measure of Sampling Adequacy. & .949 \\
\hline \multirow{3}{*}{ Bartlett's Test of Sphericity } & Approx. Chi-Square & 7574.103 \\
\cline { 2 - 3 } & df & 325 \\
\cline { 2 - 3 } & Sig. & .000 \\
\hline
\end{tabular}


Paper - The Ethical Perception of Engineering Students Who Have Never Participated in the Ethics...

Table 7. Rotated component matrixa

\begin{tabular}{|c|c|c|c|c|}
\hline \multirow{2}{*}{ Items } & \multicolumn{4}{|c|}{ Component } \\
\hline & 1 & 2 & 3 & 4 \\
\hline I26 & .719 & & & \\
\hline 125 & .698 & & & \\
\hline I23 & .692 & & & \\
\hline I24 & .627 & & & \\
\hline I27 & .603 & & & \\
\hline I 21 & .603 & & & \\
\hline I20 & .540 & & & \\
\hline \multicolumn{5}{|l|}{$\mathrm{I22}$} \\
\hline I6 & & .753 & & \\
\hline I19 & & .729 & & \\
\hline I7 & & .665 & & \\
\hline I8 & & .625 & & \\
\hline I10 & & .569 & & \\
\hline I15 & & & .674 & \\
\hline I17 & & & .665 & \\
\hline I14 & & & .617 & \\
\hline I13 & & & .582 & \\
\hline I16 & & & .560 & \\
\hline I18 & & & .532 & \\
\hline I5 & & & .502 & \\
\hline \multicolumn{5}{|l|}{ I12 } \\
\hline I3 & & & & .649 \\
\hline I4 & & & & .587 \\
\hline \begin{tabular}{|l|}
12 \\
\end{tabular} & & & & .557 \\
\hline \multicolumn{5}{|l|}{ I9 } \\
\hline I11 & & & & \\
\hline
\end{tabular}

Extraction Method: Principal Component Analysis.

Rotation Method: Varimax with Kaiser Normalization.

a. Rotation converged in 8 iterations. 